\title{
Analysis Of Brand Equity Toward Consumer Attitudes In Ija Kroeng Products In Banda Aceh
}

\author{
Rahmi $^{1}$, Nelly $^{2}$ \\ \{rahmi@serambimekkah.ac.id, nelly@serambimekkah.ac.id $\}$ \\ ${ }^{1), 2)}$ Lecturers of Management Studies Program Faculty of Economics Serambi Mekkah University
}

\begin{abstract}
The attitude of consumers is to learn the tendency of consumers to evaluate the brand both that is consistently liked or disliked. Brand equity is the value of a brand, depend the extent to which the brand has high loyalty, the quality that is accepted by consumers and able to add more value to consumers. One of the factors that influences brand equity is the attitude of consumers towards a brand. This study was aimed to analyse brand equity toward consumer attitudes in Ija Kroeng products in Banda Aceh. The sample of this study was 100 respondents. The data used in this study was quantitative data. The type of data used was primary data and secondary data. The data used in this study was quantitative data and using convenience sampling technique. The results showed that brand equity had a significant effect on consumer attitudes in Ija Kroeng products in Banda Aceh, it was proven by brand equity as factors that influence the attitude of consumers. While partially brand equity have a significant effect on consumer attitudes in Ija Kroeng products in Banda Aceh, with the value of $t_{\text {count }}>t_{\text {table }}$ $(2,051>1,984)$.
\end{abstract}

Keywords: Brand equity, Consumer attitudes.

\section{Introduction}

Brand is the identity of a product that can be used as a measuring instrument whether the product is good and has a quality. Consumers see a brand as the most important part of a product, and a brand can be a value added in the product. Brands can add more value to consumers. Consumers are willing to pay more for a product because it attaches a brand which is a guarantee of the consistency of certain qualities and values that are believed it has, without a consumer brand, the consumers feel less secure of bad possibilities beyond expectations.

According to [1], brand equity is the value of a brand, dependon the extent to which the brand has high loyalty, awareness of name, quality received, strong brand associations, and other assets such as trademark patents and relationships channel. Factors that can affect brand equity are consumer attitudes towards a brand. Attitude is also an important component in purchasing behaviour. In the decision making process, attitudes become one of the variables of consumer thinking in addition to the need factor. Knowing the consumer's attitude towards a product brand, it means knowing the brand's position in the eyes of consumers. Consumers' attitude towards brands is a tendency that consumers learn to evaluate brands by supporting (positive) or not supporting (negatively) consistently.

Sarong for the people of Aceh is a necessity, none of Acehnese do not have it. Even in traditional events in Aceh, sarong must be part of the seserahan (giving jewelery and clothing 
for the bride) for the wedding procession. This versatile cloth also accommodates the daily life of the Acehnese people to carry out worship. And the children who recite in the mosque or traditional Islamic boarding school also wear sarong, so that a sarongor in the local language is called Ija Kroeng is not just clothes, but a cultural identity.

The first idea to give the brand name of Ija Kroeng is in the daily life of the community, the word to mention the sarong is Ija Kroeng. And so far the name of a product is rarely used as a brand name, but for Ija Kroeng, in Acehnese society it is indeed a term that is familiar to every community. So that the use of the Ija Kroeng name is expected to be easily recognized by the public, because in Aceh, once people call the Ija Kroeng, then surely everyone will understand that it is a sarong. The story of a sarong or in the local language called Ija Kroeng is not limited to clothes, but is a cultural identity. So far, sarong is identical with square or stripe, well, today Ija Kroeng wants to introduce a different, trendy and modern design, so that it can be worn by everyone from anywhere, from young people to even old people will be satisfied and comfortable in wearing sarong with Ija Kroeng brand.

\section{Research Method}

This research was conducted at Workshop Ija Kroeng which is located at Jalan Teuku Umar Lr. Mahya No. 51, Setui, Banda Aceh. This study discussed the analysis of brand equity towards consumer attitudes in Ija Kroeng products in Banda Aceh. The type of data used was primary data and secondary data. The number of respondents taken as samples were 100 respondents, using convenience sampling technique.

\subsection{Consumer Attitude}

According to [2] attitude is a picture of the feelings of a consumer, and these feelings will be reflected by their behaviour. According to [3] the attitude is to study the tendency to respond to an object or group of objects whether they are liked or disliked consistently. According to Hawkins in [4] attitude is the process of organizing motivation, emotion, perception, cognitive that is long-term and related to the surrounding environmental aspect. According to [5] the attitude of consumers is to learn the tendency of consumers to evaluate the brand both that is consistently likedor disliked.

According to [2] stated that there are several models of consumer attitudes towards brands, namely:

1. The tri component attitude model. Consumer attitude towards a product is formed from three components, namely trust (cognitive), emotional (affective), and desire to behave (conative).

2. Multi attribute attitude model. The multi attribute model explains that the consumer's attitude towards an attitude model (product or brand) is very much determined by the consumer's attitude towards the attributes evaluated. The model is called multi attribute because consumer evaluation of objects is based on its evaluation of many attributes possessed by the object.

3. Ideal point model (ideal-number model) explains that this ideal number model provides information about consumer attitudes towards a product's brand and can also provide information about the ideal brand perceived by consumers.

According to [6] the factors that influence consumer attitudes toward brands are culture, social factors, personal, psychological. Some of these factors are not considered by marketers 
but actually must be reckoned in order to find out how far the factors of consumer behaviour affect consumer purchases.

\subsection{Brand Equity}

According to [6] brand equity is a positive differential effect caused by knowing the brand name of customer responses to the product or service. According to [1],brand equity is the value of a brand, depend on the extent to which the brand has high loyalty, awareness of name, quality received, strong brand associations, and other assets such as trademark patents and relationships channel.According to [7], Brand equity is an important intangible asset, which has psychological and financial value for the company. While Aaker in [7] brand equity is a device of five categories of brand assets and liabilities relating to brands that increase or decrease the value given by a product or service to companies and / or customers. According to Erdem \& Swait in [8]brand equity is the value of a product sent to consumers. According to David Aaker in [8] brand equity is a set of brand assets and liabilities associated with a brand, name and symbol, which adds or reduces the value of a product or service to the company and / or its customers.

\subsubsection{Brand Equity Dimensions}

According to [9], brand equity can provide value to the company, namely:

1. Strong brand equity can help a company in an effort to attract the interest of potential customers as well as efforts to establish good relationships with consumers and can eliminate consumer doubts about brand quality.

2. All elements of brand equity can influence consumer purchasing decisions because strong brand equity will reduce consumers' desire to move to other brands.

3. Consumers who have high loyalty to a brand will not be easy to move to competing brands, even though competitors have made product innovations.

4. Brand associations will be useful for companies to evaluate the decision of brand extension strategies.

5. Companies that have strong brand equity can determine premium prices and reduce the company's dependence on promotion.

6. Companies that have strong brand equity can save money when the company decides to expand its brand.

7. Strong brand equity will create distribution channel loyalty that will increase the number of company sales.

8. Four strong core elements of brand equity (brand awareness, brand association, perceived quality, and brand loyalty) can increase the strengths of other brand equity such as consumer confidence, and others.

\subsubsection{Factors Affecting Brand Equity}

According to Aaker in [8] that there are five factors in brand equity, namely:

1. Brand awareness is an element of equity that is very important for the company because brand awareness can directly affect brand equity.

2. Brand associations as everything that is connected in consumer memory to a brand.

3. Perceived quality, consumer's perception of the quality or excellence of a product or service in relation to the desired goals, compared to other alternatives.

4. Brand loyalty is a measure of consumer interest in a brand.

5. Other assets related to brands (other brand-related assets). 


\section{Result Discussion}

Overview of Ija Kroeng Local wisdom in sarong has been widely known since the days of the kingdom of Aceh Darussalam in the 17th century. Versatile fabrics that can be used by the community for various opportunities also become clothing across caste, age and gender. The culture of sarong for the people of Aceh has been known since childhood. The story of a sarong or in the local language called Ija Kroeng is not limited to clothes, but is a cultural identity. The first idea to give the brand name of Ija Kroeng is in the daily life of the community, the word to mention the sarong is Ija Kroeng. And so far the name of a product is rarely used as a brand name, but for Ija Kroeng, in Acehnese society it is indeed a term that is familiar to every community. So that the use of the Ija Kroeng name is expected to be easily recognized by the public, because in Aceh, once people call the Ija Kroeng, then surely everyone will understand that it is a sarong. The Ija Kroeng was firstly produced with a plain motif, namely black and white. The Ija Kroeng's products have been produced more modern and modified more beautiful, for example with Rencong handle motifs, modified Aceh door motifs, king stamp motifs (sikureueng stamp), and continue to be developed in a variety of unique Acehnese motifs. So far, sarong is identical with square or stripe, well, today Ija Kroeng wants to introduce a different, trendy and modern design, so that it can be worn by everyone from anywhere, from young people to even old people will be satisfied and comfortable in wearing sarong with Ija Kroeng brand.

Table 1.1Validity Test Results

\begin{tabular}{llllcl}
\hline No & Variable & Item & Value Rcalculating & Value Rtable $(\mathrm{N}=100)$ & Descripstion \\
\hline 1 & Consum & C1 & 0,606 & 0,194 & Valid \\
& er & C2 & 0,626 & 0,194 & Valid \\
& Attitude & C3 & 0,551 & 0,194 & Valid \\
& s & C4 & 0,685 & 0,194 & Valid \\
& (Y) & C5 & 0,413 & 0,194 & Valid \\
2 & Brand & A1 & 0,659 & 0,194 & Valid \\
& Equity & A2 & 0,752 & 0,194 & Valid \\
& (X) & A3 & 0,503 & 0,194 & Valid \\
& & A4 & 0,749 & 0,194 & Valid \\
& A5 & 0,659 & 0,194 & Valid
\end{tabular}

Source: Primary Data, 2018 (processed)

Based on Table 4.1, the results of testing the validity of each variable are:

1. Consumer Attitude Variable (Y)

Validity testing results for the consumer attitude variable (Y) which consists of 5 (five) statement items denoted by the item code C1, C2, to C5, shows the lowest $r_{\text {count }}$ value of 0.413 , this number is greater than the $r_{\text {table }}$ value $(n=100)$ of 0.194 , so it can be interpreted that all statement items related to consumer attitudes are declared valid.

2. Brand Equity Variables (X)

The results of validity testing for brand equity variable (X) consisting of 5 (five) statement items are denoted by the item code A1, A2, A3 to A5, showing the lowest $\mathrm{r}_{\text {count }}$ value of 0.503 , this number is greater than the $r_{\text {table }}$ value $(n=100)$ was 0.194 , so that it can be interpreted that all statement items related to the brand equity variable are declared valid. 
Based on the elaboration above it is clear that all statement items in each research variable namely consumer attitudes and brand equity are declared valid, which means the questionnaire used for data collection can be used to measure what should be measured.

Table 2 Reliability Test Results

\begin{tabular}{ccccc}
\hline No & Variable & $\begin{array}{c}\text { Total } \\
\text { Item }\end{array}$ & $\begin{array}{c}\text { Value } \\
\text { Cronb } \\
\text { ach Alpha }\end{array}$ & $\begin{array}{l}\text { Descript } \\
\text { ion }\end{array}$ \\
\hline 1 & $\begin{array}{c}\text { Consume } \\
\text { r Attitudes } \\
\text { (Y) }\end{array}$ & 5 & 0,719 & Reliable \\
2 & $\begin{array}{c}\text { Brand } \\
\text { Equity (X) }\end{array}$ & 5 & 0,761 & Reliable \\
\hline
\end{tabular}

Source: Primary Data, 2018 (processed)

Based on Table 4.2, the consumer attitude variable (Y) with the Cronbach alpha value of 0.719 , and the results of reliability can be seen that the alpha for each variable can be seen, namely the brand equity variable $(\mathrm{X})$ with the Cronbach alpha value of 0.761 . This the measurement of reliability of the research variables shows that the measurement of reliability meets the credibility of Cronbach Alpha where the alpha value is $>0.60$. Analysis of Brand Equity towards Consumer Attitudes in Ija Kroeng Products in Banda Aceh. The t (partial) test was conducted to find the effect of the independent variable on the dependent variable in the regression equation partially by assuming other variables which are considered constant. The test was done by comparing the value of $t_{\text {count }}$ with the value of $t_{\text {table, namely. The hypothesis }}$ for the variable consumer attitudes showed the value of $t_{\text {count }}>t_{\text {table }}(2.051>1.984)$, then partially has brand equity a significant effect on the consumer attitude in Ija Kroeng products in Banda Aceh, so the second hypothesis $\mathrm{H}_{\mathrm{a}}$ is accepted. That partially brand equity have a significant effect on consumer attitudes in Ija Kroeng products in Banda Aceh. This means that brand equity can significantly increase consumer attitudes in Ija Kroeng products in Banda Aceh.

\section{Conclusions}

Based on the results of the research researchers have carried out, it can be concluded as follows: Brand equity affect the Consumer attitudes of Ija Kroeng products in Banda Aceh, with a value of $t_{\text {count }}>t_{\text {table }}(2.051>1.984)$. ). This shows that the positive attitude shown by consumers on consumer attitudes will increase the brand equity in Ija Kroeng products in Banda Aceh.

\section{References}

[1] P. Kotler and G. Armstrong, Marketing Management Analysis, Planning, Implementation and Control. Jakarta: SalembaEmpat, 2009.

[2] U. Sumarwan, Consumer Behaviour. Bogor: Ghalia Indonesia, 2009.

[3] Sutisna, Consumer Behaviour and Marketing Communication. Bandung: PT.Remaja Rosda Karya, 2008.

[4] E. Ferrinadewi, Brand and Consumer Psychology: Implications in Marketing Strategies. 
Yogyakarta: GrahaIlmu, 2009.

[5] S. Nugroho, Consumer behaviour. Jakarta: Prenada Media, 2008.

[6] P. Kotler, Marketing Management. Jakarta: PT. Index, 2009.

[7] P. Kotler and K. L. Keller, Marketing Management. Jakarta: PT. Index: Jakarta., 2009.

[8] F. Tjiptono, Marketing Business Strategy. Yogyakarta: Andi, 2009.

[9] D. Darmadi, Sugiarto, and S. Tony, Market Overpowering Strategy Through Equity Research and Brand Behavior. Jakarta: PT. Gramedia, 2009. 